Stephen M. Maurer*

\title{
The New Self-Governance: A Theoretical Framework
}

\begin{abstract}
Industry has organized increasingly effective self-governance initiatives since the 1980s. Almost all of these are based on the economic leverage of large retailers and manufacturers over their worldwide supply chains. This article documents commonalities in six of the best-studied examples-coffee, dolphin-safe tuna, fisheries, lumber, food processing, and artificial DNA-and offers straightforward economic and political theories to explain them. The theories teach that oligopoly competition can strongly constrain private power so that firms are answerable to a shadow electorate of consumers. Furthermore, rational firms often benefit from ceding significant power to suppliers and NGOs. These results extend traditional arguments that free markets constrain private power and suggest an explicit framework for deciding when private politics are legitimate. ${ }^{1}$
\end{abstract}

\section{Introduction}

The rise of globalization in the 1980s required the construction of new supply chains that paired the economic muscle of large western firms with worldwide compliance networks. While the system was originally built to enforce price and quantity terms, it works equally well for any standard that imposes costly behaviors on supply chains. The past twenty years have exploited this power to organize increasingly ambitious private regulatory initiatives that are only distantly

1 I thank Paul Seabright and the Institute for Advanced Studies at Toulouse for generously hosting me during the first phase of this work. I also thank Tim Büthe, Errol Meidinger, Tim Lytton, The Reading Group on Private Regulation, and two anonymous reviewers for their helpful comments. Any errors are mine alone. Above all, I am indebted to the late Suzanne Scotchmer for her characteristically shrewd observation that quality competition can drive oligopolists' (economic) profits to zero. This is for you.

*Corresponding author: Stephen M. Maurer, Adjunct (Full) Professor of Public Policy, Goldman School of Public Policy, University of California, 2607 Hearst Ave., Berkeley, CA. 94720-9657, USA, Tel.: 510-725-5168, e-mail: smaurer@berkeley.edu. 
related to profitability. ${ }^{2}$ Examples include product safety, environmental sustainability, and limiting the spread of biological weapons. The resulting compliance burdens are often comparable to those imposed by governments.

Depending on the circumstances, private bodies can offer important advantages compared to traditional regulation. First, they almost always act faster than governments. ${ }^{3}$ Second, they offer a second chance when conventional politics deadlock. ${ }^{4}$ Third, private standards are coextensive with markets. This lets them reach across national borders to regulate vast areas and, in some cases, the entire world. Fourth, the private sector possesses deep monitoring and enforcement resources. These sometimes exceed host government capacity, ${ }^{5}$ particularly in the developing world. ${ }^{6}$ Finally, industry almost always possesses superior information and technical expertise about which goals are achievable and how to minimize costs. ${ }^{7}$

The existing scholarly literature consists largely of case studies. By comparison, comments on the economics and politics of standards, though often insightful, are little more than asides. Arguments for legitimacy are particularly ad hoc. For now, the most elaborate efforts have come from practitioners rather than scholars, most notably ISEAL's "Credibility Principles" and "Code of Good Practices." 8 These documents endorse various virtues ("sustainability," "engagement," "transparency") and institutional architectures, most notably that decisions should be made by less-than-unanimous "consensus." Most of these concepts are venerated by traditions that go back to the 1920s. ${ }^{9}$ However, those standards bodies were very different from their modern counterparts and, in any case, ISEAL has never explained why it expects its proposed virtues to advance democracy or any other normative goal. This makes it nearly impossible to answer such obvious questions as "how much consensus is enough?" or "does the amount of required consensus decrease when organizations are more transparent?" The vagueness is even worse when we recall that ISEAL's virtues can sometimes produce unintended consequences, as when "transparency" makes it easier for illicit cartels to detect cheating and punish defectors. Plainly, we should be careful what we ask for. Faced with this analytical weakness, many scholars have retreated into "output legitimacy," i.e., embracing organizations that have

\footnotetext{
2 Gereffi (1994, 1999).

3 Pitofsky (1998).

4 Büthe (2010).

5 Büthe and Mattli (2011).

6 Mayer and Gereffi (2010).

7 Pitofski (1998).

$8 \operatorname{ISEAL}(2013,2014)$.

9 Russell (2014).
} 
produced good (or at least mainstream) results in the past. ${ }^{10}$ But this says nothing about how good outcomes can be engineered, let alone how to spot bad institutions before they cause damage.

This paper takes a different tack. We use the literature's rich case studies to construct a positive theory of when private power is possible and the extent to which it reflects opinion in the broader society. In contrast to previous authors who proceeded from political science and sociology concepts, we start from the detailed microeconomics of private power. Here, the close resemblance between private self-governance and other, more conventionally commercial standards suggest that similar profit-and-loss incentives must be at work. In some cases, we will see that our economic analysis confirms results previously found by other methods. More importantly, we break new ground by showing how a "critical mass" of downstream firms can impose industry-wide rules on their suppliers-unanimity is not required. We argue that this economic fact enforces a de facto constitution or "voting rule" against which private politics can proceed. Finally, we will see that our economic focus provides a natural way to generalize traditional political arguments that marketplace competition provides important safeguards against plutocracy and private power.

We proceed as follows. Section 2 argues that real markets offer opportunities for both individual choice and collective action and that these often coexist within the same standard. It also sketches the history of industry self-governance since the nineteenth century. Section 3 describes some of the best-studied examples of the new self-governance. Section 4 builds on these examples to construct an economic theory of private power. Section 5 explores the politics which decide how this power is deployed, identifying specific circumstances where actors are constrained by market forces or else rationally decide to share power with others. Section 6 matches our models of private power and politics against traditional arguments that invoke free markets as a corrective to private power. Section 7 presents a brief conclusion.

\section{Private Power: Some Basic Concepts and History}

Traditional governments implement law through their monopoly of violence, most notably by jailing dissenters who defy duly enacted statutes. ${ }^{11}$ Mainstream opinion nevertheless holds that this compulsion is sometimes legitimate. The reason is that many problems can only be solved by collective action, so that letting one naysayer

10 Bekkers and Edwards (2007).

11 Weber (1919). 
veto action disenfranchises the entire society. "Veil of ignorance" arguments formalize this point by showing that no utility-maximizing citizen would agree to a constitution that banned all collective action ex ante. ${ }^{12}$

Power in Markets. Private self-governance, like all collective action, rests on coercion. The difference for private actors is that the coercion never escalates beyond profit and loss to physical violence. But escalation is not always necessary: In many cases, we expect financial incentives to achieve compliance all by themselves. The distinction between financial penalties and other sanctions is especially thin for entities, where negative profits really do inflict a kind of death penalty by forcing firms to halt operations.

In practice, private power almost always involves the use of standards. However, the converse is not true: Many standards confer no power at all. Consider, for example, a private standard that lets consumers know whether their products are made by socially responsible methods. Here the basic strategy is to eliminate a market defect by supplying information. But the standard itself is content-neutral: While the improved market empowers consumers who favor social responsibility, those who disagree can proceed as before. This is what competitive markets are supposed to do.

The case is very different where standards operate in imperfect markets. Here, individual choice is reduced so that more consumers buy products incorporating standards they disagree with. From a normative standpoint, this could well be desirable if (a) some solutions are impossible without collective action, and (b) disenfranchised consumers are in the minority. More generally, the same standard often empowers some choices and disables others. ${ }^{13}$ Furthermore, this balance can shift. This means that initially optional standards can become progressively less voluntary and even evolve into government mandates over time. ${ }^{14}$

Traditional Models. Private firms have experimented with different self-governance models since the nineteenth century. In general, there are three variants. The first, so-called "shadow of hierarchy" case is when government coerces private self-governance through legislation or threats of regulation. ${ }^{15}$ However, this seldom happens unless regulators feel so strongly about an issue that they leave private actors little or no discretion. For this reason, theorists usually treat private preferences and politics as a minor correction to official goals. ${ }^{16}$

12 Brennan and Buchanan (1985); Rawls (1999).

13 Fischer and Lyon (2014).

14 Brousseau and Raynaud (2011).

15 See Gupta and Lad (1983).

16 See Dawson and Segerson (2008). 
The second model is based on so-called "network" industries that require agreed standards to be profitable. Familiar examples include insurance company fire codes, certification bodies that help consumers confirm the quality of goods and services, or standards bodies for interoperable equipment. ${ }^{17}$ In practice, most network issues are narrowly technical. This ensures that private politics is mostly about profit maximization and seldom implicates deep social values.

Our third and final model occurs when a handful of large corporations possess economic leverage over hundreds of small firms that need repeat business to survive. ${ }^{18}$ The most spectacular pre-1980s example was garment manufacturers' efforts to set up government-like agencies to punish "business ethics" violations by small retail outlets in the Great Depression. The Supreme Court angrily replied that the Sherman Act banned such "extra-judicial tribunals for [the] determination and punishment of violations." ${ }^{19}$ While the phrase has never been clearly defined-nobody believes that the court meant to overturn every private standard in America-the basic lesson that private power is at least sometimes illegal has never been challenged. ${ }^{20}$ The new private power radically extends this third model and the legitimacy issues that come with it.

The New Private Power. Modern global supply chains were invented to extract and enforce price and quality concessions. However, this same machinery can enforce practically any behavior. Modern industry self-regulation is almost always constructed around transnational supply chains. ${ }^{21}$

The proliferation of new (and newly powerful) governance bodies made legitimacy questions more urgent. On the one hand, traditional "one man, one vote" prescriptions make no sense for bodies whose members (a) are drawn from self-selected enthusiasts who look very different from the broader population, and (b) often include entities as well as individuals. Private standards bodies usually finesse the problem by adopting corporatist structures in which different interest groups meet in "chambers" which must separately approve any action. ${ }^{22}$ However, this leaves the further difficulty that the chambers themselves are almost never unanimous. The concept of "consensus" is meant to fix this. Despite this, the term is only partly defined and consists largely of negative definitions. The most important include the absence of "sustained opposition" to "substantial issues" by all "concerned interests," with unspecified additional protections to those

\footnotetext{
17 See King and Lenox (2000); Furger (1997); Garvin (1983).

18 See Garvin (1983).

19 U.S. Supreme Court (1941).

20 Maurer (2014).

21 Meidinger (2008); Gereffi (1994, 1999).

22 ISEAL (2014).
} 
“directly affected." ${ }^{23}$ In practice, prominent standards bodies sometimes stretch "consensus" to include three-to-one supermajorities. ${ }^{24}$ This hints at a pragmatic principle that standards bodies should not alienate so many members that walkouts lead to collapse.

\section{Motivating Examples}

Scholars have devoted a large literature to describing industry self-governance since the 1980s. In practice, most examples bear a strong family resemblance to one another. This section documents the point by reviewing how private power and politics have played out for six particularly well-studied initiatives. ${ }^{25}$

Tuna. Newspapers began carrying alarming accounts of tuna fishermen killing dolphins in the 1980s. Knowing that consumer backlash could permanently depress demand, Star Kist-the world's largest processor-developed dolphin-safe standards with the NGO Earth Island. The company then announced that it would only purchase tuna caught according to its standard. Competing canners Chicken of the Sea and Bumble Bee adopted identical policies almost immediately. Together, the three companies accounted for 84 percent of U.S. canned tuna sales and nearly half the world market. ${ }^{26}$ The standard also benefited from U.S. diplomatic pressure and subsequent legislation creating an official standard that occasionally contradicted the private one. ${ }^{27}$ However, these effects appear to have had relatively little impact: Industry practice does not seem to have changed since the World Trade Organization struck down the U.S. standard in 2012.28

In a perfect market suppliers would have built one set of facilities for dolphinfriendly customers and a second set for everyone else. In practice, economies of scale made it cheaper to apply the higher standard for all purposes. Twenty years later, 471 companies in sixty-seven countries had joined the scheme. The new rules required significant effort, most notably paying Earth Island to regularly inspect canneries, docks, and fishing vessels. By 2007 worldwide dolphin mortality from fishing had been cut from eighty thousand to three thousand per year. ${ }^{29}$

23 Id.

24 Forest Stewardship Council (2012).

25 See Maurer (2014) and Maurer (2011) for further discussion of the collaborations described in this section.

26 Golan, Kuchler, and Mitchell (2001).

27 Id.

28 Carman (2012).

29 Conroy (2007). 
For all its power, the tuna initiative's politics was remarkably simple: one large company imposing rules that could be written on a single sheet of paper. Industry inevitably started to consider bigger alliances and more elaborate regulations.

Food. European supermarkets reacted to the Mad Cow disease scandals of the mid1990s by imposing strict food safety standards on their suppliers. Since most small suppliers depended on "huge retailer[s] they could not afford to lose," ${ }^{30}$ resistance was minimal. Despite this, proliferating standards forced suppliers to maintain duplicate facilities while restricting the number of suppliers who could compete for any given order. This raised supermarket costs. Retailers responded by creating harmonized standards for the United Kingdom (1996), Germany and France (2002), and the United States (2003). ${ }^{31}$ But long-distance trade was still needlessly complex. In 2004 thirteen large retailers tried to replace all three standards with a harmonized 'Global Gap' standard. Perversely, all four standards survived, creating a situation that was at least arguably worse than it had been before. ${ }^{32}$ Meanwhile, individual supermarkets realized that they could join more than one standard at a time. In 2000, large retailers launched a Global Food Safety Initiative (GFSI) to certify which standards were acceptable. By 2006 GFSI had certified all four regional standards and covered roughly 65 percent of worldwide retail food sales. ${ }^{33}$

The first food standards were drawn up by retailers who knew relatively little about what measures were feasible or efficient. Yet suppliers were reluctant to disclose information that could be used to demand still more concessions. Retailers addressed this in three different ways. First, they announced compliance targets several years into the future. Whether or not these deadlines were met, retailers who upgraded compliance were more likely to win competitive bids. ${ }^{34}$ Second, Global Gap and GFSI opened their memberships so that suppliers exercised roughly as much power as retailers. ${ }^{35}$ This gave suppliers a chance to block or at least moderate further demands. Finally, the major standards competed for adherents. This meant that improvements by one standard often spread to the others. ${ }^{36}$ Global Gap also shared power with NGOs, ${ }^{37}$ though in this case the goal was less about gathering information than persuading trusted intermediaries to reassure consumers that the standard was credible.

30 Wellik (2012)

31 Fuchs et al. (2008).

32 Id.

33 Id.

34 Wellik (2012).

35 Fuchs et al. (2008); Kalfagianni (2010).

36 Meidinger (2008); Zeitlin and Overdest (2014).

37 Fuchs et al. (2008). 
These private standards were remarkably strong. Scholars agree that retailers' leverage amounts to "power in a Dahlian sense"38 and has been sufficiently burdensome to drive many small farmers out of the market. ${ }^{39}$ It was also vigorous enough to persuade the European Union that formal regulation was unnecessary. ${ }^{40}$

Fisheries. Processed food giant Unilever became concerned with collapsing fishery stocks and stalled government treaty negotiations in the 1990s. By 1995 it had partnered with the World Wildlife Federation (WWF) to regulate fishermen. ${ }^{41}$ As with WWF's lumber initiative, the fishermen themselves were not consulted. The partners did, however, work with government scientists, activists, academics, and industry to reduce the existing diplomatic consensus to an enforceable Principles document. ${ }^{42}$ The draft was discussed at eight subsequent stakeholder meetings and finalized by yet another expert group in December 1997. Unilever and WWF launched an independent Marine Stewardship Council (MSC) to implement the Principles in $1999 .{ }^{43}$

MSC's fifteen member board relies on pre-approved outside firms to draft plans for bringing each new fishery into compliance with the Principles. The board then certifies or rejects each plan. ${ }^{44}$ Compliance is expensive: Fisheries pay up to $\$ 500,000$ for plans and must often agree to expensive new practices. ${ }^{45}$ For premium species like salmon this investment pays for itself in the form of higher prices. ${ }^{46}$ More often, retailers use MSC certification to attract and defend market share without raising prices. ${ }^{47}$

By 2012 MSC had certified more than one hundred fisheries including the enormous Alaskan pollock and South African hake fisheries. ${ }^{48}$ This often included significant concessions like posting independent observers on boats, limiting the fishing season, and restricting when lines can be set. ${ }^{49}$ Like dolphin-safe tuna, processors usually find it cheaper to switch to a single standard than to operate

38 Büthe (2010); Fuchs and Kalfagianni (2010).

39 Fuchs and Kalfagianni (2010); Campbell and LeHeron (2007).

40 Fuchs and Kalfagianni (2010).

41 Howes (2008); Hale (2011).

42 Wortman (2002).

43 Unilever (2003).

44 Hale (2011)

45 Id.

46 Howes (2008).

47 Maurer (2014).

48 Unilever (2003).

49 Hale (2011). 
redundant facilities. This, in turn, increased certified stocks to the point where large retailers could join the standard without fear of supply interruptions. ${ }^{50}$

MSC originally hoped that the Principles would limit its certification firms' discretion in designing plans. ${ }^{51}$ This would have left little room for politics. In practice, however, most observers agree that setting eighty to one hundred unique performance goals for each fishery affords significant flexibility. ${ }^{52}$ This means that many plan negotiations become "highly politicized" with fisheries and environmentalist groups each threatening to abandon MSC unless their demands are met. ${ }^{53}$ While MSC's board has the last word over each plan, they also know that MSC needs both reliable fish supplies and NGO endorsements to survive. Presumably, the board balances outcomes so that each side receives more concessions than it would get by walking away.

Lumber. Rich nation diplomacy to protect tropical rainforests collapsed in 1992. WWF responded by organizing the Forest Stewardship Council (FSC) to reduce the existing diplomatic consensus to enforceable rules. ${ }^{54}$ Much of this work was funded by Austrian officials who had seen earlier, more formal regulation struck down in court. ${ }^{55}$

The FSC adopted an elaborate corporatist architecture in which measures had to be approved by six sub-chambers. ${ }^{56}$ Like MSC, FSC made little effort to woo producers and even adopted voting rules that made suppliers a permanent minority. ${ }^{57}$ Instead, its activist allies tried to shame large retailers into forcing standards onto their supply chains. The strategy worked well in the highly concentrated home improvement industry. In 1999 Home Depot announced a "long-term intention" to transition its entire inventory to suppliers "following rules that only FSC currently meets." ${ }^{58}$ This was quickly followed by other home improvement firms. By 2002 roughly one-fourth of the U.S. market had expressed a purchasing preference for FSC. ${ }^{59}$ However, this support was overwhelmingly focused on large suppliers like Weyerhaeuser. Buyers in more competitive industries (e.g.,

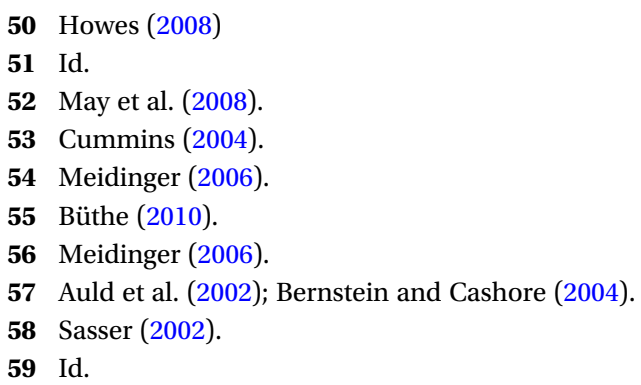


homebuilding) continued to buy lumber from small landowners at the lowest available price. ${ }^{60}$

Producers fought back by creating their own national standards bodies. While the worldwide Programme for the Endorsement of Forest Certification (PEFC) recognized the same diplomatic consensus as FSC, it interpreted it much more narrowly. ${ }^{61}$ Moreover, any viable standards body must attract both suppliers and consumers to survive. This forced FSC and PEFC to woo each others' constituencies and led to considerable convergence over time. ${ }^{62}$ Despite this, neither standard has disappeared. Industry observers claim that the continuing conflict drains resources that would be better spent extending the standards to new forests. ${ }^{63}$

Even so, private lumber regulation is impressive. Roughly 10 percent of the world's forests currently fall under at least one standard, with PEFC leading FSC by a two-to-one margin. ${ }^{64}$ Back-of-the-envelope arguments suggest that compliance can sometimes cost up to 10 percent of revenues. ${ }^{65}$ Since wood is more fungible than fish, land taken out of service by private standards is usually replaced by uncertified production elsewhere. Even so, this is still a significant improvement except for the unlikely case where the new land is more vulnerable on average than the relatively small tracts that the standards protect from harvesting. ${ }^{66}$

Coffee. U.S. and European governments first organized coffee cartels to shore up Latin American political stability in the 1940s. These collapsed after the Cold War leading to a 40 percent drop in coffee prices followed by persistent volatility to the present day. ${ }^{67}$ While NGOs developed private standards for the roughly 10 percent of consumers willing to pay a premium for sustainability, this did nothing for the broader market. ${ }^{68}$

In 2001 the German government, Kraft, Nestlé, Sara Lee, and Tschibo agreed to pursue a "Common Code for Coffee" Association (4C) that would create minimum standards for the entire industry. Thirty-five big coffee companies, producers, and NGOs worked on the draft code. Negotiations proceeded by a series of "we'll join if you'll join" discussions punctuated by threatened or, in a few cases,

60 Brown and Zhang (2005).

61 Meidinger (2008).

62 Id.

63 Rotherham (2011).

64 UN Economic Commission for Europe (2012).

65 Maurer (2013).

66 Maurer (2013).

67 International Coffee Organization (2013).

68 4C Association (2007). 
actual walkouts. ${ }^{69}$ This led to a baseline coffee standard in 2004 and a corporatiststyle governance architecture with leadership elections in 2007. The work was facilitated by a professional staff that identified points of potential agreement and provided enough transparency so that all sides were sufficiently confident to accept proposals. ${ }^{70}$

The 4C Association standards currently extend to 240,000 workers, ban a variety of "unacceptable practices," and commit participants to steadily improve still more practices over time. ${ }^{71}$ Despite this, the process has been marked by ongoing suspicion between the growers and western coffee companies. The basic difficulty is that (a) coffee companies fear that the growers will pocket higher prices without investing in infrastructure, and (b) growers fear that the companies will never buy enough 4C-compliant coffee to repay their compliance costs. ${ }^{72}$ Looking back, the growers' fears may well have been justified. Despite recent efforts to expand purchases, western companies' demand for 4C compliant coffee is only about one-fifth of supply. ${ }^{73}$ This suggests that the existing standard could yet disappear if growers stop investing and allow compliance to atrophy.

Synthetic DNA. Companies have manufactured and sold artificial DNA since 1999: Five years later academic scientists had used the product to make polio ${ }^{74}$ and 1918 influenza viruses. ${ }^{75}$ This suggested that terrorists and rogue states could soon make smallpox and/or engineered biological weapons that do not exist in nature. ${ }^{76}$ After $9 / 11$ the U.S. government began discussing regulations specifying what DNA companies should do to investigate customer orders. However, the process was painfully slow. ${ }^{77}$ In 2007 a small German trade association moved to fill the vacuum by creating a private standard. After extensive negotiation, members agreed on a process that required $\mathrm{PhD}$ biologists to study some customer orders for up to two hours. ${ }^{78}$ This was a significant burden in an industry where the average order cost just \$10,000. ${ }^{79}$ In mid-2009 an American trade association

69 Künkel et al. (2008).

70 Id.

71 4C Association (2009).

72 Künkel et al. (2008).

73 4C Association (2014).

74 Cello et al. (2002).

75 Tumpey et al. (2005).

76 Maurer (2011).

77 Id.

78 International Association-Synthetic Biology (2009).

79 Maurer et al. (2009). 
proposed an automated alternative that promised to be cheaper but also less effective. ${ }^{80}$ Nature gleefully reported that a "standards war" had broken out. ${ }^{81}$

The German group met to revise their draft standard in October. The outside observers included one of the industry's biggest customers (Astra-Zeneca), some American companies linked to the opposing standard, several U.S. government officials, and Nature. While Astra-Zeneca plainly wanted suppliers to self-regulate, it scrupulously avoided endorsing any specific level of effort. ${ }^{82}$ This delegated essentially all power to suppliers except, perhaps, for the right to do nothing at all. The October meeting ended with the German companies finalizing and implementing their standard. Within weeks, two large Chinese companies announced that they, too, would comply. ${ }^{83}$ This was presumably done to preserve access to western markets in general and big pharmaceutical companies in particular. Meanwhile the big American firms announced a competing but substantively indistinguishable standard of their own. ${ }^{84}$

There was still one surprise left. In late November the U.S. governmentunder heavy lobbying from the American firms-announced non-binding "guidelines" that relied entirely on computers. ${ }^{85}$ This was cheaper and also less capable than the standards that industry had already agreed to. At this point, many industry executives began arguing that further private standards were unnecessary since their companies were already doing more than the U.S. government wanted. Internal industry discussions aimed at developing further private standards essentially stopped at this point. ${ }^{86}$

\section{Economics of Private Power}

Private standards are an amphibian process: Their power is rooted in economics but their execution is political. This section concentrates on the first part of the analysis. We return to politics in the next section.

Commonalities. Our case studies show striking similarities. First, all of our initiatives include at least one large firm. While this was usually a retailer in our examples, we note that large manufacturers like Boeing or agri-business producers like

80 Maurer (2011).

81 Check (2009).

82 Maurer (2011).

83 Id.

84 International Gene Synthesis Consortium (2009).

85 U.S. Dept. of Health \& Human Services (2009).

86 Markus Fischer, Chief Executive Officer, Entelechon GmbH (personal communication). 
StarKist (in our tuna example) often exercise similar power over their supply chains. For this reason, we will use the more generic phrase "anchor firm(s)" to describe them in what follows. Second, suppliers are invariably much smaller and more numerous than the anchor firms they sell to. This market structure immediately implies strong competition and low unit margins. Finally, suppliers face substantial fixed costs for investments in $R \& D$, equipment, training, or years spent building customer relationships. This is evidenced, among other things, by their aversion to duplicated facilities.

Power. The combination of high fixed costs and low unit margins means that suppliers must maintain consistently high sales volumes to survive. Anchor firms often take advantage of this by offering "preferred supplier" agreements in which producers trade deep price and quality concessions for a steady flow of orders. ${ }^{87}$ The point, of course, is that the anchor firm can rescind the agreement if its supplier fails to perform. For the anchor firm, shifting business to other vendors is a nuisance and can lead to slightly higher unit prices. For the terminated supplier, however, the shift is catastrophic. Lacking sales volume, its unit costs skyrocket. This cuts into profits and can force the company to raise prices so much that it loses still more sales. In some cases, the supplier can even become unprofitable and leave the industry entirely. ${ }^{88}$ The bottom line is that anchor firms possess huge leverage for demanding price, quality, and any other terms they want. This explains the existing literature's semi-empirical observation that self-governance systems are frequently dominated by "all-powerful global brands [that] are willing and able to dictate commercial terms ... on their 'weak' and/or 'dependent' suppliers," 89 and approximately corresponds to Gereffi et al.'s typology of "captive" and "relational" supply chains. ${ }^{90}$

Formal economic models of this argument lead to a crucial insight: Anchor firms don't have to be unanimous to impose uniform, industry-wide standard on their suppliers. ${ }^{91}$ At some point - the exact threshold depends on market structure-the fact that some anchor firms oppose the higher standard no longer matters. The reason is that the dissenters no longer control enough demand to pay the fixed costs for even one supplier.

Remarkably, certain types of risk make private standards easier to organize. Legal scholars have traditionally focused on accidents in civilian industries:

87 Maurer et al. (2009).

88 von Engelhardt and Maurer (2012); Maurer and von Engelhardt (2013).

89 Locke (2013).

90 Gereffi, Humphrey, and Sturgeon (2005).

91 Id. 
Here, risk exposure from court judgments or increased regulation is roughly proportional to sales volume and behaves like a variable cost. The case is very different, however, when the threat is intelligent and malicious. For example, terrorist groups only need to obtain synthetic DNA once to make a weapon. For these industries, (a) every supplier incurs risk as soon as it offers its product for sale, and (b) this risk never changes no matter how many or how few units it sells. Here, risk behaves like a fixed cost. This gives anchor firms even more leverage to demand self-governance. ${ }^{92}$

Enforcement. Standards only matter when they are observed. Most scholarly skepticism to private regulation is based on an instinct that firms have an incentive to cheat. Here the definitive analysis is due to Shapiro, who explored a formal model in which firms that pretend to practice high standards can extract a premium from consumers until they are caught. He found that enforcement is only effective where (a) deceptions are immediately discovered, or (b) firms that observe the standard earn a premium whose discounted value exceeds the expected value of cheating. ${ }^{93}$ Scarpa has shown that a similar analysis applies to third party auditors, who can usually earn a one-time profit by quietly defunding enforcement. ${ }^{94}$

This work provides a deep objection to the traditional "shadow of hierarchy" and network effects schemes described in Section 2. But the New Self-Governance is different. The reason is that the anchor firms that demand self-governance really do benefit from enforcement. Conversely, anchor firms earn nothing when suppliers cheat and stand to lose significant market share when the cheating is exposed. Of course, the suppliers themselves still have good reason to cheat. But this is exactly what the new global supply chains were built to prevent. Anecdotal evidence supports this view: While anchor firm executives commonly fight over how much to prioritize standards enforcement, everyone understands that cheating is dangerous and sometimes muster sufficient agreement to terminate violators. ${ }^{95}$

\section{Private Politics}

We have argued that a critical mass of anchor firms - the exact fraction is an accident of market structure-can impose a universal standard on suppliers. In the

92 Maurer and von Engelhardt (2013).

93 Shapiro (1983).

94 Scarpa (1999).

95 Banjo (2014). 
language of politics, this defines a "voting rule" or "constitution." But having a constitution is not the same as knowing outcomes. For that, we also need to understand (a) what anchor firms want, and (b) the politics and institutions that translate these preferences into actual standards.

Commonalities. Once again, our examples share important commonalities: First, anchor firms often delegate substantial power to suppliers. Second, politics frequently proceed by walk-out threats. Third, members who do walk out often form competing standards bodies. Indeed, this is exactly what happened in our lumber and DNA cases. Finally, anchor firms only occasionally extract a price premium from adopting private standards. More often, adherence is used to gain or defend market share. This supplies a broad hint that elite preferences are strongly constrained by oligopoly competition and the need to please consumers.

Policy Preferences. All politics starts with some well-defined elite who control the levers of power. For reasons already discussed, that power resides in the dominant downstream anchor firms. We therefore identify our elite with the list of executives, shareholders, employees, and other parties who exercise de jure or de facto control within those corporations. However this is only a first approximation. Depending on market structure, these individuals may often find that their discretion is limited by the need to please other actors. Conceptually, there are three possible endmodels. We have already said that the first possibility-perfectly competitive markets-gives each consumer exactly what they want. Our anchor firm-dominated supply chains bear very little resemblance to this model. This is just as well: Political scientists have long realized that private standards cannot survive perfect competition. ${ }^{96}$

The second possible end-model is monopoly, whether exercised by a single firm or a cartel. Within broad limits, monopoly lets executives do what they like so long as the company breaks even. Individual executives exercise power in pursuit of personal preferences which in turn reflect a complex mix of greed, ethics, professional norms, peer pressure, ideology, and perceived social obligation. ${ }^{97}$ Industrial organization scholars claim that increased competition, the rise of institutional investors, and changes in executive compensation have steadily eroded this kind of executive discretion since the 1960s. ${ }^{98}$

96 McConnell (1963).

97 Vogel (2005).

98 Id. 
Our final possible end-model involves oligopolies that successfully suppress price competition so that prices are "rigid" and change much less than underlying costs. ${ }^{99}$ Crucially, this suppression often fails to suppress competition along such other dimensions as product quality, psychic attributes (e.g., celebrity endorsements) and-most significantly for our purposes-social responsibility. Furthermore, this "non-price competition" can be extraordinarily hard to suppress since (a) quality upgrades often resemble ordinary product differentiation, and (b) rivals must upgrade their own products to punish violators. The resulting delays in detecting and punishing violations makes cheating even more tempting. ${ }^{100}$ The net result is that non-price competition can be fierce and even drive participants' economic profits to zero. ${ }^{101}$ Empirically, this often manifests itself as an obsession with market share: Because prices are similar, there is nothing to stop shoppers from switching brands overnight. This makes consumers into a kind of "shadow electorate" that limits company choice in much the same way that ordinary voters constrain elected officials. ${ }^{102}$

Walkouts, Delegation, and Transparency. The fact that anchor firms can impose standards on suppliers does not necessarily mean that it is in their interest to do so. Sometimes, they can do better by delegating some or even all of their power to others. One reason is informational: As in our food example, suppliers almost always know more about how to implement reforms more thoroughly and affordably than outsiders do. Where the information asymmetry is large (e.g., artificial DNA), anchor firms may cede their power entirely. The second reason is credibility. The fact that companies are behaving virtuously is almost always more valuable when consumers believe it. This encourages anchor firms to share power with NGO partners who can vouch for their behavior.

In both cases we have seen that the bargain is enforced by walkout threats. Presumably, this reflects a judgment that those who join the initiative can exert more influence than they would by leaving. This is not to say that each participant receives as much influence as they "ought" to possess in a normative sense. But if policymakers think that a group should have more power, the most natural remedy is to bolster its bargaining position by making its walkout threat more credible. This can most easily be done by enhancing its access to agencies, courts, and public opinion. In the meantime, if a well-known green group, say, agrees to serve on a

99 Anderton (2000).

100 Bumas (1999).

101 Id.

102 Maurer (2014). 
private forestry initiative we should normally assume that the environment really will benefit. Of course, delegations can always be rescinded. So long as they last, however, the power seems real enough.

External Politics. Given perfect information, we expect voters to select whichever agenda serves their interests until a winning coalition emerges. ${ }^{103}$ This process is reasonably straightforward where knowledgeable actors negotiate face-to-face. However, voters in complex institutions often suffer from "information impactedness" that leaves them vulnerable to deliberately incomplete or distorted information. ${ }^{104}$ Voters who try to overcome this problem by seeking advice from knowledgeable third parties similarly run the risk of hidden agendas. In some cases, impactedness can be so severe that voters decide that it is better to take no action at all. ${ }^{105}$

Government institutions almost always try to reduce impactedness through hearings and debate. However, Farrell and Saloner point out that Silicon Valleystyle standards wars provide a powerful alternative for many types of information. ${ }^{106}$ This "external politics" between standards was prominent in our food, forestry, and DNA examples. Standards wars are particularly useful for revealing economic information. For example, DNA manufacturers often argued about whether human screening was affordable. ${ }^{107}$ This kind of accounting question was nearly impossible to resolve through conventional hearings and debate. By comparison, affordability was (or at least should have been) immediately obvious once firms began voluntarily screening on their own. ${ }^{108}$ Second, conventional politics encourages competing campaign platforms to make deliberately ambiguous and even dishonest promises. ${ }^{109}$ This tactic is much less tempting in standards wars, where proposals are implemented immediately so that voters can experience each proposal first-hand. Finally, standards must attract adherents to survive. This forces competitors to bid for the same constituencies so that standards converge over time. The downside of this process-as in our forestry example-is that rival standards bodies seldom disappear entirely. ${ }^{110}$ This produces wasteful duplication and mutual attacks that weaken both organizations. ${ }^{111}$

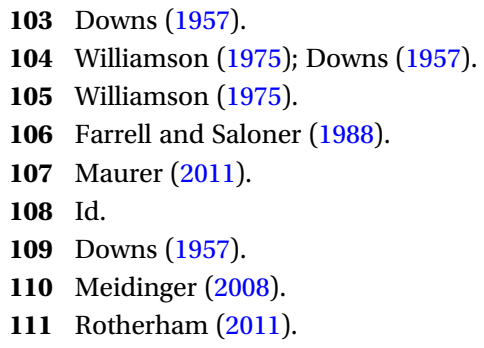


Interactions With Government. Developing private standards absorbs executives' time and energy. We therefore expect companies to stop when new information suggests that investing in the private standard is no longer profitable in expectation. At this point, public standards are likely to crowd out private standards entirely.

The details of this calculation will usually depend on why industry launched a private standard to begin with. Where the goal is to preempt public regulation, evidence that government plans to enact strong regulations no matter what industry does will normally crowd out private standards. The case is slightly different, however, where industry sees private standards as insurance against deadlocked or inadequate public regulation. Here, industry is only likely to abandon private initiatives when it becomes convinced that regulators will produce an acceptable outcome regardless. This is especially true since the costs of completing the private standard will normally fall over time as more work is done.

As usual, there is no guarantee that industry's incentives to abandon a private standard will produce the best social outcome. To the contrary: We have argued that private standards can strengthen public regulation by generating otherwise unavailable information on political feasibility, technology options, and affordability. This suggests that private and public governance initiatives should be encouraged to run in parallel for as long as possible.

\section{Normative \& Legal Implications}

We have argued that anchor firms' private power is often constrained by shadow electorates and rational incentives to share power with interest groups like suppliers and NGOs. These constraints recall traditional arguments that politicians are constrained by their need for reelection. This section makes these intuitions precise.

Markets \& Democracy. Eighteenth and nineteenth century political theorists argued that competitive markets limit private power and can even neutralize it entirely. The basic point was that competition constrains profit margins so that any company that tries to exert power will soon go out of business. ${ }^{112}$ This is equivalent to our earlier point that perfect markets empower consumer choice.

By comparison, monopoly gives executives maximal freedom so long as they earn some small positive profit. In principle, this might be legitimate so long as the monopolists' views are not too different from the broader society. The argument is

112 Hofstadter (1991); Millon (1991). 
especially tempting in an age where business elites often hold mainstream or even-in the case of Hollywood and Silicon Valley-left-of-center views. ${ }^{113}$ Despite this, U.S. courts and political philosophers have consistently held that it does not matter whether companies are benign or not. Rather, the mere possibility of abuse is unacceptable. ${ }^{114}$ Our analysis adds little to these arguments one way or the other.

We have already noted the end-state in which non-price competition continues to the point where firms earn no (economic) profit at all. When this happens companies must respect consumer opinion for much the same reason that elected officials pander to polls. Furthermore, this shadow electorate includes a convincingly large cross-section of the population: Indeed, the number of Americans who regularly shop at Target is about the same as those who vote in US midterm elections. ${ }^{115}$ This provides a brute force solution to the so-called "citizenship" objection that those affected by private rules should also help chose them. ${ }^{116}$

Of course, real industries will usually contain admixtures of our end-states. Here, real anchor firms will often find themselves able to exercise significant discretion without going broke. Even so, the force of this objection is limited. After all, the U.S. electoral system is also imperfect. This gives officials significant freedom to engage in venality and, more optimistically, public virtue. Discretion by corporate elites should be similarly acceptable, with due adjustment for the (questionable) hypothesis that American politicians are more public-regarding on average.

Finally, one might worry that our shadow electorate cannot speak clearly because the market reduces consumers' multidimensional social responsibility, product quality, and psychological preferences to a unitary yes/no decision. The answer, again, is that conventional elections are no better. Except for the relatively unusual case of referenda, voters are almost always asked to decide based on an uncomfortable mix of policy preferences, self-interest ("pocket book issues"), and candidate charisma.

Delegation, Transparency and Institutional Architectures. Whether or not markets constrain power in the first instance, institutions in which anchor firms convincingly delegate power to the main affected interests should be considered legitimate. These institutions are admittedly imperfect since anchor firms can always

113 Nelson (2015); Chait (2012).

114 U.S. Supreme Court (1948).

115 Langley (2014); Wikipedia (n.d.).

116 Meidinger (2008). 
rescind their delegation. For this reason, the range of possible outcomes almost certainly excludes results that anchor firms strongly oppose. Even so, it seems better to let private initiatives empower some democratic outcomes than none at all.

Finally, our framework provides a theoretical context for ISEAL's otherwise obscure talk of "consensus" and "transparency." According to our analysis, consensus in and of itself has nothing to do with legitimacy. That can only come from "the people" or at least our shadow electorate. Consensus does, however, provide a convenient estimator for measuring what the shadow electorate actually thinks. Indeed, MSC's board established several advisory bodies for just this reason after some of its decisions unexpectedly angered the public. ${ }^{117}$ Similarly, transparency vis a vis the outside world increases shadow electorates' ability to impose their will. Finally, internal transparency reduces the chances that members' votes will be skewed by limited or distorted information.

Antitrust Law. U.S. officials have repeatedly said that "legitimate and well-intentioned self-regulation" is desirable. ${ }^{118}$ However, we have seen that current doctrine is confused. This deters anchor firms who might otherwise support selfgovernance. ${ }^{119}$ Rationalizing the doctrine would immediately remove this impediment.

We have already said that the Sherman Act has both a political and an economic purpose. The political purpose is older and originates in the instinct that free markets limit private power. Extending these ideas to include non-price competition seems straightforward. The more difficult question is when private standards violate economic efficiency. While the law permits standards that are essential to creating an effective market, non-economic goals remain suspect. ${ }^{120}$ This makes little sense since banning private standards automatically sets the goals' value to zero. This is surely the worst possible outcome: If business takes a problem seriously enough to tax itself, even a small tax will normally be preferable to doing nothing. Finally, judges often worry that private standards can be used as "sham agreements" whose real purpose is cartelization. These fears may often be reasonable where agreements (a) require parties to pay fees that change their marginal costs and therefore the prices they charge, ${ }^{121}$ or (b) set goals (e.g., regulating specific technologies) that systematically favor some firms over others.

117 Cummins (2004).

118 Pitofsky (1998).

119 Maurer (2014).

120 U.S. Supreme Court (1984).

121 Maurer and Scotchmer (2014). 
Conversely, judges should normally accept standards that specify facially neutral goals (e.g., limiting dolphin mortality) while leaving firms free to design their own compliance methods.

Interactions With Traditional Government. Industries often adopt standards to preempt formal - and presumably more aggressive-regulation. ${ }^{122}$ But this does not necessarily argue that self-regulation is undesirable. After all, public agencies have limited regulatory resources and must unavoidably prioritize. This means that private regulation-selfish or no-is often the only way to regulate minor activities. ${ }^{123}$ More generally, if industry reforms make formal regulation less urgent, agencies really should reallocate their resources where they can do more good. This argument would be even stronger in a world where most firms self-regulate so that regulators' attention is eventually deflected back to their original targets.

Private standards can also strengthen formal regulation. We have already remarked that private regulation can provide useful information. Private standards are also a convenient way to coordinate solutions across national borders. This limits the danger of inconsistent regulation and reduces the political costs of negotiating formal harmonization treaties later. This suggests that governments should be careful not to crowd out parallel private standards prematurely, and perhaps not at all.

Neo-Imperialism. Modern self-governance almost always starts with rich nation companies trying to please rich nation consumers. Using this power to impose rules on the developing world is probably the strongest argument against legitimacy. ${ }^{124}$ Logically, the only possible responses are (a) that the end justifies the means ("output legitimacy"), or (b) that private politics is at least as democratic as the local institutions it displaces. The latter argument will be much more persuasive if developing world partners concede legitimacy because the private initiative features a federalist structure that gives them disproportionate influence over outcomes. This is another version of our argument that anchor firms often find it in their interest to cede significant power to suppliers.

Other Legitimacy Theories. This paper's "shadow electorate" viewpoint fits most naturally with those branches of democratic theory that emphasize voting and representation. While this is probably the dominant strand in the existing literature, the fact that private bodies cannot hold formal elections remains analytically

122 Büthe (2010).

123 Pitofsky (1998).

124 Meidinger (2008). 
awkward. This has persuaded many self-governance scholars to take a second look at alternative theories of democratic legitimacy including "deliberative" theories in which reasoned debate leads to outcomes that are best for society, ${ }^{125}$ "output legitimacy" theories in which institutions act in ways that gain public approval ex post, ${ }^{126}$ and semi-empirical arguments that any institution that citizens willingly defer to should be considered legitimate. ${ }^{127}$

The common assumption in all of these theories is that differences of opinion can be resolved in ways that the losing side will eventually agree to. This result seems plausible where the debate centers on finding the best solutions for implementing widely-agreed upon values like food safety or suppressing weapons of mass destruction. While market forces will continue to empower "shadow electorates" in all of these cases, their legitimacy implications are less clear. At best, shadow electorates will provide a safeguard against institutions delivering results that the public disapproves of. At worst, they may occasionally disable leaders from pursuing solutions that a more enlightened public would eventually want.

The deeper problem is what to do when private governance faces disputes over normative goals that are both deeply held and unlikely to change on human timescales. In these cases, insisting that legitimacy can only proceed from institutions that, say, obtain consensus from reasoned debate sets a very high bar. Even if a few private governance institutions will meet the test, many more will be outlawed tout court. But we should be reluctant to banish such potentially useful institutions so easily. Instead, we return to our original observation that collective action almost always involves overruling dissenters. There are, of course, many legitimacy theories (e.g., "dictatorship of the proletariat," "divine right of kings") that explain why dissent can and should be overruled. Since the French Revolution, however, liberal democratic theory has almost always invoked just one acceptable solution-popular elections. Accepting our "shadow electorates" argument extends this indispensable element to private governance.

\section{Conclusion}

We have presented a positive theory of how private power originates and the politics that control it. However, this framework is only a starting point. While we have argued that self-governance can sometimes be legitimate, we have deliberately avoided any estimate of how often these conditions are met or even whether the

125 Meidinger (2008).

126 Bekkers and Edwards (2007).

127 Suchman (1995). 
particular examples discussed in Section 3 are themselves legitimate. Answering these questions will require industry-specific investigations into how much discretion firms actually possess; whether they have convincingly delegated power to the principal affected interests; and whether institutional architectures provide an internally- and externally-transparent process. Relevant evidence will normally include showing that executives fear consumer outrage; that anchor firms possess and routinely exploit economic leverage to enforce above-normal price and quality terms; and that non-price competition has kept anchor firms profits at or below normal returns to investment in the U.S. economy.

These, however, are well-defined questions. The genius of the Sherman Act was that it moved the debate over private power from wooly political discussion to objective questions of competition and market structure. The current framework updates this analysis to include non-price competition and argues that consumers provide a convincing shadow electorate. The fact that this electorate was originally organized for economic instead of political reasons hardly matters. If we care about democracy, it should not matter where we find it.

\section{References}

4C Association. 2009. Annual Report [on file with author].

—. 2014. “Annual Report 2013: Propagating a Sustainable Coffee Community.” Bonn, Germany: 4C Association. http://www.4C-coffeeassociation.org/latest/2014/4C-annual-report-out-now (Accessed November 2, 2016).

— . 2007. “Annual Report 2007: Engaging the World's Coffee Growers, Traders, Processors, Marketers and Civil Society to Continuously Increase the Sustainability of Coffee Through Responsible Social, Economic and Environmental Stewardship.” Bonn, Germany: $4 \mathrm{C}$ Association. https://www.scribd.com/document/311695171/4C-Annual-Report-2007 (Accessed November 2, 2016).

Anderton, Alain. 2000. Economics, 3rd edition. London: Pearson Education Ltd.

Auld, Graeme, Benjamin Cashore, Cristina Balboa, Laura Bozzi, and Stefan Renckens. 2010. "Can Technological Innovations Improve Private Regulation in the Global Economy?” Business \& Politics 12 (3): 1-42.

Banjo, Shelly. 21 April 2014. “Inside Nike’s Struggle to Balance Cost and Worker Safety in Bangladesh." The Wall Street Journal.

Bekkers, Victor and Arthur Edwards. 2007. "Legitimacy and Democracy: A Conceptual Framework for Assessing Government Practices." In Governance and the Democratic Deficit: Assessing the Democratic Legitimacy of Governance Practices, edited by Viktor Bekkers, Geske Dijkstra, Arthur Edwards, and Mengo Fenger. Aldershot, UK: Ashgate.

Bernstein, Steven and Benjamin Cashore. 2004. "Nonstate Global Governance: Is Forest Certification a Legitimate Alternative to a Global Forest Convention?" In Hard Choices, Soft Law: Voluntary Standards in Global Trade, Environment, and Social Governance, edited by John J. Kirton and Michael J. Trebilcock. Aldershot, UK: Ashgate. 
Brousseau, Eric and Emmaneul Raynaud. 2011. "Climbing the Hierarchical Ladders of Rules: A LifeCycle Theory of Institutional Evolution.” Journal of Economic Behavior \& Organization 79: 65-79.

Brown, Roger and Daowei Zhang. 2005. "The Sustainable Forestry Initiative's Impact on Stumpage Markets in the US South." Canadian Journal of Forest Research 35 (20): 56-64.

Buchanan, James and Geoffrey Brennan. 1985. The Reason of Rules: Constitutional Political Economy. Cambridge: Cambridge University Press.

Bumas, Lester 0. 1999. Intermediate Microeconomics: Neoclassical and Factually-Oriented Models. New York: M.E. Sharpe, Inc.

Büthe, Tim. 2011. "Engineering Uncontestedness? The Origins and Institutional Development of the International Electrotechnical Commission (IEC)." Business and Policy 12 (3).

Büthe, Tim. 2010. "Private Regulation in the Global Economy: A (P)Review." Business and Policy 12 (3).

Büthe, Tim and Walter Mattli. 2011. The New Global Rulers: The Privatization of Regulation in the World Economy. Princeton, NJ: Princeton University Press.

Campbell, Hugh and Richard Le Heron. 2007. "Supermarkets, Producers, and Audit Technologies: The Constitutive Micro-Politics of Food, Legitimacy, and Governance." In Supermarkets and Agrifood Supply Chains: Transformations in the Production and Consumption of Foods, edited by David Burch and Geoffrey Lawrence. Cheltenham, UK: Edward Elgar.

Carman, Tim. 16 May 2012. "WTO: 'Dolphin-Safe' Label Discriminates Against Mexico." The Washington Post.

Cello, Jeronimo, Aniko V. Paul, and Eckard Wimmer. 2002. "Chemical Synthesis of Poliovirus cDNA: Generation of Infectious Virus in the Absence of Natural Template." Science 297 (5583): 1016-1018.

Chait, Jonathan. 19 August 2012. "The Vast Left-Wing Conspiracy is on Your Screen.” New York Magazine.

Check, Erica E. 2009. “Keeping Genes Out of Terrorists' Hands.” Nature 461: 22.

Conroy, Michael E. 2007. Branded! How the 'Certification Revolution' is Transforming Global Corporations. Gabriola Island, Canada: New Society Publishers.

Cummins, Alexia. 2004. "The Marine Stewardship Council: A Multi-Stakeholder Approach to Sustainable Fishing." Corporate Social Responsibility and Environmental Management 11: 85-94.

Dawson, Na Li and Kathleen Segerson. 2008. "Voluntary Agreement With Industries: Participation Incentives With Industry-Wide Targets." Land Economics 84: 97-114.

Downs, Anthony. 1957. An Economic Theory of Democracy. New York: Harper.

Farrell, Joseph and Garth Saloner. 1988. "Coordination Through Committees and Markets." RAND J. Econ. 19: 235.

Fischer, Carolyn and Thomas P. Lyon. 2014. "Competing Environmental Labels." Journal of Economics and Management Strategy 23: 692.

Forest Stewardship Council. 2012. FSC International Standard: "FSC Principles and Criteria for Forest Stewardship.” https://ic.fsc.org/the-revised-pc.191.htm (Accessed January 6, 2017).

Fuchs, Doris and Agni Kalfagianni. 2010. "The Causes and Consequences of Private Food Governance." Business \& Policy 12 (3).

Fuchs, Doris, Agni Kalfagianni and Tetty Havinga. 2008. “Actors in Private Food Governance: The Legitimacy of Retail Standards and Multistakeholder Initiatives With Civil Society Participation." Agriculture and Human Values 28 (3): 53-67.

Furger, Franco. 1997. "Accountability and Systems of Self-Governance: The Case of the Maritime Industry." Law and Policy 19: 445-476. 
Garvin, David A. 1983. “Can Self-Regulation Work?” California Management Review 25(4): 37-52. Gereffi, Gary, John Humphrey, and Timothy Sturgeon. 2005. "The Governance of Global Value Chains." Review of International Political Economy 12 (1): 78-104.

Gereffi, Gary. 1994. "The Organization of Buyer-Driven Global Commodity Chains: How US Retailers Shape Overseas Production Networks." In Commodity Chains and Global Capitalism edited by In Gary Gereffi and Miguel Korzeniewicz. Westport, CT: Praeger.

Gereffi, Gary. 1999. "International Trade and Industrial Upgrading in the Apparel Commodity Chain." Journal of International Economics 48 (1): 37-70.

Golan, Elise, Fred Kuchler and Lorainne Mitchell. 2001. “Economics of Food Labeling.” Journal of Consumer Policy 24: 117.

Gupta, Anil K. and Lawrence J. Lad. 1983. "Industry Self-Regulation: An Economic, Organizational, and Political Analysis." Academy of Management Review 8: 416-425.

Hale, Thomas. 2011. "Marine Stewardship Council." In Handbook of Transnational Governance: Institutions and Innovations, edited by Thomas Hale and David Held. Cambridge, UK: Polity Press.

Hofstadter, Richard. 1991. "What Happened to the Antitrust Movement?" In The Political Economy of the Sherman Act: The First One Hundred Years, edited by E. Thomas Sullivan. Oxford: Oxford University Press.

Howes, Rupert. 2008. “The Marine Stewardship Council Programme.” In Seafood Labeling: Principles and Practice, edited by Trevor Ward and Bruce Philips. Hoboken, NJ: WileyBlackwell.

International Association - Synthetic Biology. 2009. "Code of Conduct for Best Practices in Gene Synthesis.” http://www.ia-sb.eu/tasks/sites/syntheticbiology/assets/File/pdf/iasb_code_of_ conduct_final.pdf (Accessed January 4, 2017). Copy on file with the author.

International Coffee Organization. 2013. The International Coffee Organization 1963-2013: 50 Years Serving the World Coffee Community. London, UK: International Coffee Organization. http://www.ico.org/documents/cy2012-13/history-ico-50-years-e.pdf (Accessed November 2, 2016).

International Social and Environmental Accreditation and Labelling Alliance (ISEAL). 2013. “Credibility Principles Brochure: What's Essential for a Standards System to Deliver Positive Impact?” http://issuu.com/isealalliance/docs/credibility_principles_booklet?e=3335187/ 3992107 (Accessed November 2, 2016).

—. 2014. "Setting Social and Environmental Standards: ISEAL Code of Good Practice Version 6.0.” http://issuu.com/isealalliance/docs/iseal_standard_setting_code_v6_dec_ee=3335187/ 11610938 (Accessed January 6, 2017).

International Gene Synthesis Consortium. 2009. "Harmonized Screening Protocol: Gene Sequence \& Customer Screening to Promote Biosecurity.” http://www.genesynthesisconsortium.org/ images/pdf/IGSC\%20Harmonized\%20Screening\%20Protocol-11_18_09.pdf (Accessed November 2, 2016).

Kalfagianni, Agni. 2010. "The Effectiveness of Private Food (Retail) Governance for Sustainability." Working Paper: Vrije Universiteit Amsterdam: Institute for Environmental Studies.

King, Andrew and Michael Lenox. 2000. "Industry Self-Regulation Without Sanctions: The Chemical Industry's Responsible Care Program." Academy of Management Review 43: 698-716.

Künkel, Petra, Vera Fricke, and Stanislava Cholakova. 2008. Case Study: "The Common Code for the Coffee Community (4C)." (Draft) On-file with the author and Google archive. 
Langley, Monica. 2014. “Inside Target, CEO Struggles to Regain Shoppers' Trust.” Wall Street Journal (Feb. 19).

Locke, Richard M. 2013. The Promise and Limits of Private Power: Promoting Labor Standards in a Global Economy. Cambridge: Cambridge University Press.

Maurer, Stephen M. 2014. "Public Problems, Private Answers: Reforming Industry Self-Governance for the 21st Century." DePaul Business and Commercial Law Journal 12 (3): 297-360.

Maurer, Stephen M. and Suzanne Scotchmer. 2014. "The Essential Facilities Doctrine: The Lost Message of Terminal Railroad." California Law Review: Circuit (Oct. 8).

Maurer, Stephen M. and Sebastian v Engelhardt. 2013. "Industry Self-Governance: A New Way to Manage Dangerous Technologies." Bulletin of the Atomic Scientists (May).

Maurer, Stephen M. 2011. "End of the Beginning or Beginning of the End? Synthetic Biology's Stalled Security Agenda and the Prospects for Restarting It." Valparaiso University Law Review 45 (4): 1387-1446.

Maurer, Stephen M., Markus Fischer, Heinz Schwer, et al. 2009. “Making Commercial Biology Safer: What the Gene Synthesis Industry Has Learned About Screening Customers and Orders." Working Paper: University of California Berkeley. Goldman School of Public Policy. https://gspp.berkeley.edu/assets/uploads/page/Maurer_IASB_Screening.pdf (Accessed November 2, 2016).

May, Brendan, Duncan Leadbitter, and Michael Weber. 2008. "The Marine Stewardship Council: What is It All About?" In Ecolabelling in Fisheries: What Is It All About? edited by Bruce Phillips, Trevor Ward, and Chet Chaffee. Hoboken, NJ: Wiley-Blackwell.

McConnell, Grant. 1963. Steel and the Presidency - 1962. New York: W.W. Norton.

Meidinger, Errol. 2006. "The Administrative Law of Global Private-Public Regulation: The Case of Forestry.” European Journal of International Law 17: 47 (2016).

Meidinger, Errol. 2008. “Competitive Supragovernmental Regulation: How Could it Be Democratic?" Chicago Journal of International Law 3 (2): 512-534.

Mayer, Frederick and Gary Gereffi. 2010. "Regulation and Economic Globalization: Prospects and Limits of Private Governance." Business and Politics (October).

Millon, David. 1991. "The Sherman Act and The Balance of Power." In The Political Economy of the Sherman Act: The First One Hundred Years, edited by E. Thomas Sullivan. Oxford: Oxford University Press.

Nelson, Rebecca. 2015. “The Secret Republicans of Silicon Valley.” National Journal (April 8).

Overdevest, Christine and Jonathan Zeitlin. 2014. "Assembling an Experimentalist Regime: Transnational Governance Interactions in the Forest Sector." Regulation \& Governance 8: 22-48.

Pitofsky, Robert. 1998. DC Bar Association Symposium on "Self-Regulation and Antitrust." https:// www.ftc.gov/public-statements/1998/02/self-regulation-and-antitrust (Accessed November 2, 2016).

Russell, Andrew. 2014. Open Standards and the Digital Age: History, Ideology, and Networks. Cambridge: Cambridge University Press.

Rawls, John. 1999. A Theory of Justice. Cambridge, MA: Harvard University Press.

Rotherham, Tony. 2011. "Forest Management Certification Around the World - Progress and Problems." The Forestry Chronicle 87 (5).

Sasser, Erika N. 2002. "Gaining Leverage: NGO Influence on Certification Institutions in the Forest Products Sector." In Forest Policy for Private Forestry edited by L.D Teeter, Benjamin Cashore, and D Zhang. Wallingford, UK: CABI Publishing. 
Scarpa, Carlo. 1999. “The Theory of Quality Regulation and Self-Regulation.” In Organized Interests and Self-Regulation, edited by Bernardo Bortolotti and Gianluca Fiorentini. Oxford: Oxford University Press.

Shapiro, Carl. 1983. "Premiums for High Quality Products as Returns to Reputations." Quarterly Journal of Economics 98: 659-79.

Suchman, Mark C. 1995. "Managing Legitimacy: Strategic and Institutional Approaches." Academy of Management Review 20 (3): 571-610.

Tumpey, Terrence M., Christopher F. Basler, Patricia V. Aguilar, et al. 2005. "Characterization of the Reconstructed 1918 Spanish Influenza Pandemic Virus.” Science 310 (5745): 77-80.

Unilever Corporation. 2003. "Fishing for the Future II: Unilever's Fish Sustainability Initiative (FSI)." https://www.unilever.com/Images/2003-fishing-for-the-future-ii-unilever-s-fish-sustainabilityinitiative_tcm244-409706_1_en.pdf (Accessed January 4, 2017).

United Nations Economic Commission for Europe. 2012. Forest Products Annual Market Review 2011-2012. New York and Geneva: United Nations. http://www.unece.org/?id=30799 (Accessed January 4, 2017).

United States Department of Health and Human Services. 2009. "Screening Framework Guidance for Synthetic Double-Stranded DNA Providers.” Federal Register 2009; 74 (62): 319-327 (Nov. 27).

United States Supreme Court. 1941. Fashion Originator's Guild Inc. v. FTC, 312 U.S. 457.

— 1948. United States vs. Columbia Steel Co., 334 U.S. 495.

- 1984. National Collegiate Athletic Association v. Board of Regents of the University of Oklahoma, 486 US 85.

von Engelhardt, Sebastian and Stephen M. Maurer. 2012. "Industry Self-Governance and National Security: On the Private Control of Dual Use Technologies." Goldman School of Public Policy Working Paper GSPP12-005.

Vogel, David. 2005. The Market for Virtue: The Potential and Limits of Corporate Social Responsibility. Washington, DC: Brookings Institution Press.

Weber, Max. 1919. "Politics as a Vocation.” http://anthropos-lab.net/wp/wp-content/uploads/ 2011/12/Weber-Politics-as-a-Vocation.pdf (Accessed January 6, 2017).

Wellik, Rhonda. 2012. "Global Food Safety Initiative Improves Organizational Culture, Efficiency in Food Industry.” Food Quality and Safety (May). https://goalqpc.com/cms/docs/whitepapers/ GOALQPCFoodSafetyWhitepaper.pdf (Accessed January 4, 2017).

Wikipedia. n.d. “United States Elections 2010.” http://en.wikipedia.org/wiki/ United_States_elections,_2010 (Accessed January 6, 2017).

Williamson, Oliver E. 1975. Markets and Hierarchies: Analysis and Antitrust Implications. New York: Free Press.

Wortman, David. 2002. "Shop and Save." Sierra Magazine (Nov./Dec.). 